\title{
Supply chain management problems in the food processing industry: Implications for business performance
}

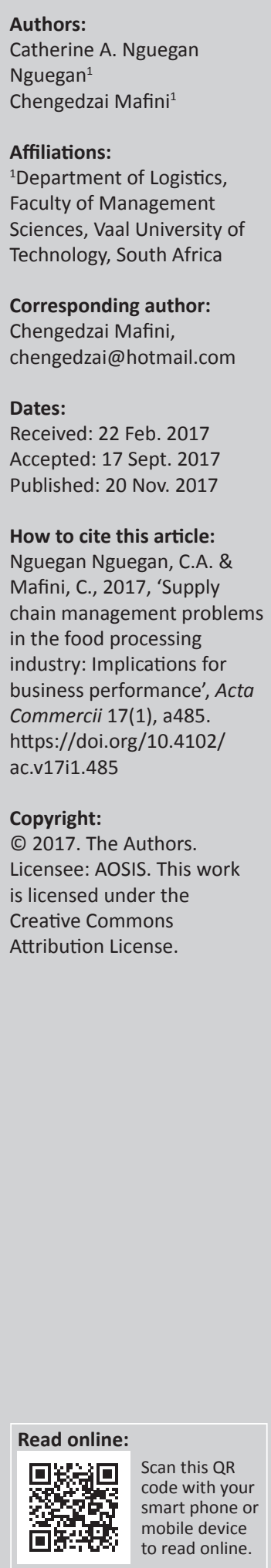

Orientation: In emerging economies such as South Africa, the implementation of supply chain management is characterised by significant problems. Despite its continued growth and importance to the economy, the food processing industry in the country remains vulnerable to these problems, which threaten its viability.

Motivation for the study: The aim of this study was to investigate supply chain management problems in the food processing industry and their influence on business performance. The study was motivated by the need to use supply chain management practices as a tool to improve business performance in the food processing industry.

Research design, approach and method: A questionnaire was distributed to a sample of 303 supply chain professionals working in the food processing industry in Gauteng Province. The collected data were analysed by using descriptive statistics, factor analysis, Pearson correlations and regression analysis.

Main findings: Supply chain management problems were identified in seven areas, namely human resource management, technology, facilities, supplier relationship management, customer relationship management, regulatory factors and logistics and transportation. Except for regulatory factors, all supply chain management problems negatively predicted business performance.

Contribution or value-add: Practically, the study enables supply chain professionals in the food processing industry to understand the sources of problems and use this information to develop solutions for the improvement of business performance. Theoretically, the study endorses the view that part of the key to resolving business performance complications in the food processing industry involves streamlining supply chain management by resolving its identifiable problems.

\section{Introduction}

South Africa is one of the top-rated emerging economies in Africa (Lewis 2017). This status is partially attributable to the contribution of various economic segments that perform an important role in satisfying the needs of consumers and contributing annually to the South African economy (Industrial Development Corporation 2016). Among these key economic segments is the food processing industry, which is one of the major industries in South Africa, generating substantial revenue for the country and providing employment opportunities to many people (Fedderke \& Szalontai 2012). Statistics South Africa (2016) reports that the food and beverages sector generated incomes of over ZAR40.2bn and nearly ZAR42.2bn in 2015 and 2016 respectively, which is indicative of its contribution to the national economy. The Department of Agriculture, Forestry and Fisheries (2014) reports that nearly 200000 people were formally employed by the food processing industry in South Africa by December 2014. Another report by the Industrial Development Corporation (2016) reiterates that the food processing industry performs an important role in ensuring food security in the country. This confirms the importance of the food processing industry to the success of the South African economy.

In spite of its economic significant contributions, South Africa's food processing industry faces diverse and demanding problems, which hinder it from growing further and realising its full potential (Cloete et al. 2012). The food processing industry in the country has changed extensively, because of the increase in the buying power of most racial groups, which resulted from the end of the oppressive apartheid dispensation as well as because of globalisation (Bac \& Erkan 2011). The industry also faces a high incidence of unpredictable customer demand and preferences, which 
influences the success and profit made by businesses (Deimel, Frentrup \& Theuvsen 2011). Unpredictable customer demand and preferences mainly stem from the availability of several substitutes for most food products, which compels consumers to switch easily from one product to the other (Cronin 2015). In addition, the food processing industry in South Africa has lagged behind in terms of technology and equipment, technical knowledge, research and development, capital, managerial and physical infrastructure (Verdouw et al. 2010). The handling of perishable food products throughout the supply chain performs an important role and requires specialised equipment such as both mobile and static refrigerators (Chung-Kee \& Chuwonganant 2014). Additionally, food safety remains a concern for most consumers, which forces governments to carefully inspect food processing methods and how the product is transported from processing sites to the marketplace (Carter \& Easton 2011). It is also noteworthy that foreign investors have taken over a larger share of the South African market by using their innovative technologies and massive capital resources (McLachlan \& Landman 2013). These problems present great pressure to the food processing industry in the country as it is still unable to generate sufficient value added products as compared to its larger foreign competitors.

It could be argued that the adoption and implementation of more recent and effective business best practices could be part of the solutions to countering the pressures facing the food processing industry. Among such business practices is supply chain management, which has emerged as an essential business activity that contributes to business performance across different industries (Janvier-James 2012). As noted by Gupta and Palsule-Desai (2011) most activities within businesses, from manufacturing to service provision, have begun to revolve around supply chain management in order to realise the ensuing proceeds. Supply chain management encompasses the planning and management of all activities involved in sourcing and procurement, conversion and all logistics management activities. Importantly, it also includes coordination and collaboration with channel partners, which can be suppliers, intermediaries, third-party service providers and customers (Council of Supply Chain Management Professionals 2010). In essence, supply chain management integrates supply and demand management within and across various organisations (Tuominen, Kitaygorodskaya \& Helo 2011). A supply chain itself may be perceived as a network linking various organisations involved upstream and downstream in either the direct or indirect production as well as the delivery of products or services to ultimate customers (Chow et al. 2010). The supply chain links every level of businesses from the raw material stage to the reverse delivery of products and information (Zhou \& Benton 2010). It is the network in which relevant information, products or services and finances flow constantly between organisations (Adebanjo 2011). As highlighted by Gold, Seuring and Beske (2011), sustainable management of the supply chain enables businesses to implement various important practices and achieve superior business performance and resource usage. Thus, individual businesses face the challenge to re-examine their best practices and determine how supply chain management activities can be embraced and implemented to ensure that business performance is optimised (Koh et al. 2011).

\section{Problem statement}

The role of supply chain management in the food processing industry is to facilitate the efficient movement of required materials, information as well as the transportation of the final product from factories to the markets close to the customers (Dharni \& Rodrigue 2015). As the food processing industry in South Africa continues to grow and increase in its complexity, so do the problems encountered in that industry (South African Poultry Association 2013). Examples of such problems include inter alia dynamic consumer tastes and demands, the need for sustainable practices and the requirement to meet cold supply chain imperatives in the transportation of food (Van Rooyen, Esterhuizen \& Stroebel 2011). The major negative effect of these problems is unsatisfactory business performance which is exhibited through, among other things, declining competitiveness and low profits (Industrial Development Corporation 2017). The availability of these problems present the food processing industry with the challenge to progress and improve in order to meet the needs of customers and the rapidly changing world of business. However, it is important that these problems be investigated through empirical research in order to develop a better understanding of the developments taking place within the industry, especially within the supply chain management context (Kumar \& Bala 2013). This may be achieved by closely analysing the different factors, from internal and external sources, that impact on the activities taking place in the supply chain (Resse 2011). Moreover, the food processing industry is an important economic segment, contributing to South Africa in terms of employment creation, provision of food which is a basic necessity and generating substantial revenue for the country (Statistics South Africa 2016). Given such importance to the South African economy, continued research is warranted to generate updated information which can be used to solve various problems experienced in this industry and to make decisions necessary for its further growth and success.

Based on the above, the aim of this study is to investigate supply chain management problems and their influence on business performance in the food processing industry in South Africa. To achieve this aim, two objectives were formulated, namely (1) to determine supply chain management problems facing the food processing industry, and (2) to establish the influence of supply chain management problems on business performance in the food processing industry.

\section{Contributions of the study}

The significance of this study lies in that the results may enable supply chain professionals in the food processing industry to understand the sources of problems and use this information to develop solutions for the improvement of 
business performance in their organisations. Analysing supply chain management problems is also crucial for businesses concerned with their operational success because management of the supply chain line has a direct impact on customer service (Pamela \& Pietro 2011). It is further noteworthy that research in supply chain management in developing countries such as South Africa is still merited because available literature in such contexts is still inadequate (Mafini, Loury-Okoumba \& Pooe 2016). In this regard, a comprehensive search of various local and international research databases revealed that literature on supply chain management problems in the food processing industry in South Africa is limited. The study is therefore an addition to literature on the role of supply chain management in shaping business performance in the food processing industry in South Africa, where there exists a need for such research.

The remainder of this article is organised as follows: the next section is a literature review of the major concepts under consideration. Thereafter, it discusses the research methods and the research results. The article closes by discussing the conclusions and managerial implications together with the limitations and suggestions for future research.

\section{Literature review}

This section provides a brief theoretical discussion of the food processing industry in South Africa, supply chain management problems and business performance.

\section{The food processing industry in South Africa}

The food processing industry is composed of businesses dedicated to the transformation of raw materials and semifinished products coming from primary activities such as agriculture, zoo technics, forestry and fishing (Cousins \& Scoones 2014). In South Africa, the largest production sectors of the food processing industry include milling, brewing, confectionery, animal, baking, soft drinks, vegetable oils, fish and meat processing (Cassim 2010). Other important food processing segments include dairy products, sugar, fruits and vegetables, liquor production, wineries and the bottling of natural spring and mineral waters (Steyn \& Labadarios 2011). This industry accounts for $18 \%$ of manufacturing sales (food $=13.2 \%$, beverages $=4.9 \%), 17 \%$ of gross value added in the manufacturing sector and employs approximately $14.5 \%$ of the total employment sector (Statistics South Africa 2017). These figures further attest to the significant contribution of the food processing industry to the South African economic landscape.

Despite its importance to the South African economy, the food processing industry has not been spared from various pressures. For instance, Gold et al. (2011) point to globalisation and diverse consumer preferences as factors impacting on the viability of the food processing industry. Woods (2014) identifies increased competition in the domestic market as a major challenge. Greenberg (2013) recognises pressures stemming from food safety, environmental and social standards, the latter of which are intended to protect both the consumer and the environment. Other pressures faced by the industry include the scarcity of water in South Africa, perishability, weather variability, the risk of infestation, rigid food quality and safety requirements, demand and price variability (Gulati et al. 2013; Van Der Vorst, Beulens \& Van Beek 2011; Widodo et al. 2006). All of these forces tend to impact on the effectiveness of supply chain management and business performance within the food processing industry (Van der Merwe 2011).

\section{Supply chain management problems}

Similar to any other business practice, supply chain management faces problems that originate either from uncertainties or the inability to coordinate several activities and partners (Otchere, Annan \& Anin 2013). Customers have become more discerning and are demanding better quality products, higher levels of service and reduced prices (Sweeney, Soutar \& McColl-Kennedy 2011). A study conducted by Groznika and Trkman (2012) identified information sharing as a critical problem between most supply chain partners, leading to the bullwhip effect. The bullwhip effect refers to fluctuations in demand in the supply chain, leading to major inventory management inefficiencies (Lee 2010). Another study conducted by Hoffman, Schiele and Krabbendam (2013) reports that risk management continues to be a problem in supply chains, based on the threat of disruptions caused by both factors within supply chains as well as external environmental forces. The sources of these risks can be from suppliers, customers or internal environment and include inter alia natural disasters, political and economic developments, changing regulations, ability to respond to technological trends, human behaviour and reduction in the supplier base (Mikes \& Kaplan 2013). Richardson and Snaddon (2011) found that stiff competition for market share remains a major problem within supply chains. Another study conducted by Stuart, Verville and Taskin (2012) pointed to the lack of buyer-supplier trust and collaboration, supplier competency and interpersonal relationships as major impediments to supply chain performance. A recent study by Pillay and Mafini (2017) identified inadequate supply chain management skills and qualifications, procurement malpractices, ineffective supply chain integration, poor supply chain relationships and industry structure as some of the challenges prevalent in supply chains in developing countries. A major question that remains pertains to whether these problems are generic to various organisations, industries and geographic regions (Rauta, Narkhede \& Gardas 2017). However, as noted by several scholars (Halldorsson et al. 2007; Li 2014; Lorentz 2009) supply chain management issues should be considered contextually, by using current trends as the foundation for decision-making and problem solving. This motivates an investigation that is specifically targeted at supply chain management problems facing the food processing industry in South Africa, where existing developments may either validate or differ from trends in other environments. 


\section{Business performance}

Business performance may be perceived as the ability of an enterprise to meet its predetermined goals (Coltman, Devinney \& Midgley 2011). It is a description of the level of fulfilled tasks within the aims of the business or targets according to obtained results at the end of a business period (Yıldız 2010). For individual businesses to be successful, every owner or manager has the task of ensuring that the business is operating as efficiently and effectively as possible (Mishra 2012; Paiva 2010). However, to improve the efficiency and effectiveness of the business a solid understanding of the most important drivers to business performance within organisations, coupled with the willingness to apply procedures to enhance these key elements, is required. A number of scholars (Andersen \& Rask 2013; Revilla \& Sáenz 2014) acknowledge that business performance is increasingly associated with supply chain management, because this leads to improvements in the flows of information, either products or services and finances. This implies that most problems in supply chain management would lead to business performance-related difficulties (Kherbach \& Mocan 2016; Li 2014).

Improving the performance of supply chains is linked to the performance of the individual business organisations operating in that supply chain (Liu, Li \& Zhao 2012; Pamela \& Pietro 2011). For instance, successful management of supply chain performance has the effect of improving communication (Munzhedzi 2011), increasing productivity (Shafritz, Russell \& Borick 2012), improving the monitoring of operations and strategies (Aguinis, Joo \& Gottfredson 2011) and enhancing problem solving and decision-making (DeNisi \& Smith 2014) of businesses within a supply chain. These benefits may have a positive effect on supply chain management systems, which may produce a link between the latter and business performance. In terms of its measurement, business performance can be measured by either subjective or objective scales because there is no single, universally valid method (Darwish \& Singh 2013). However, sometimes, both subjective and objective methods are combined in order to offset the shortcomings of either method (Muduli 2015). In this study, return on investment, sales growth, profit growth, customer satisfaction and employee satisfaction were used on a subjective scale to measure business performance in line with previous research studies (Vij \& Bedi 2016; Y1ld1z \& Karakaş 2012; Zulkiffli 2014).

\section{Research methods}

This section discusses the research design and sample, data methods and procedures, statistical analysis, scale accuracy and ethical considerations.

\section{Research design and sample}

The study used a quantitative research approach because it intended to produce comparable results that can be generalised to the food processing industry in other environments apart from Gauteng Province. In addition, a quantitative approach was chosen because it is clearer, more reliable, less time consuming and objective compared to the alternative qualitative approach (Babbie \& Mouton 2012). A crosssectional survey design was selected as the research design because data were collected from a specific population at a specific point in time (Lavrakas 2007).

The target population for this study was composed of supply chain professionals based in the food processing industry in Gauteng Province, South Africa. Gauteng was selected ahead of other provinces because it is the economic centre of South Africa, responsible for over $34.8 \%$ of South Africa's gross domestic product (GDP) and comprises the largest number of businesses in the country (South African Government 2017). This was important in facilitating the availability of businesses operating in the food processing industry. Supply chain professionals are individuals who are qualified to work in any supply chain management-related area. These areas include, but are not limited to, demand planning, logistics and transportation, manufacturing operations, procurement, customer relationship management, technology, order management and warehousing (Lambert 2014). The final sample consisted of 303 supply chain professionals employed by businesses operating in the food processing industry in Gauteng Province. These respondents were selected by means of a non-probability purposive sampling technique. This approach satisfied the need to select only those respondents that served the objectives of the study. In this instance, only those supply chain professionals who were holders of either a formal or professional qualification in any supply chain management and logistics-related field were included. Respondents were identified by the human resources departments in the participating businesses. Businesses from which the respondents were drawn were conveniently selected, given the non-availability of a single sampling frame from which a list of businesses in the food processing industry in Gauteng Province could be obtained. An internet search was conducted to identify all businesses operating in the food industry in Gauteng Province. A total of 67 businesses were identified and subsequently contacted through either email or telephone. From the 67 businesses that were invited to participate in the survey, 44 were willing to participate.

\section{Data collection methods and procedures}

Structured, self-administered questionnaires were distributed to respondents from June 2016 to August 2016. A total of 550 questionnaires were transmitted both electronically and in hard copy to the sampled respondents and then followed up for feedback. Out of this, 347 questionnaires were returned. However, from the returned questionnaires, 47 had errors and were not included in the final data analysis, leaving 303 questionnaires that were classified as useable; the 303 questionnaires used in for the analysis represent a response rate of $55 \%$. This response rate was acceptable because, as mentioned by Punch (2003), high response rates of above $50 \%$ are generally regarded as satisfactory in research and are useful in the data analysis. 
The questionnaire used in this study was divided into three sections. Section A consisted of five questions eliciting the demographic details of respondents in terms of their gender, age, race, academic qualifications and employment period. Section B consisted of 30 questions eliciting the views of respondents regarding supply chain management problems. These questions were adapted from validated scales developed by Bharthvajan (2014), McAfee, Glassman and Honeycutt (2002), Choi and Harley (1996), Lee, Lee and Pennings (2001), Grover, Chopra and Mosher (2016), Thakur and Hurburgh (2009), Bonner and Calantone (2005), Tsoulfas and Pappis (2006) and Steyn et al. (2012). Section C measured business performance by using five questionnaire items adapted from studies by Brik, Rettab and Mellahi (2011) and Maletic et al. (2015). The process of adapting these questions involved minor adjustments to the phrasing of the questions, their length and Likert-type scale configuration, in line with the recommendations by Sullivan (2011). Response options used in Section B of the measured questionnaire were presented on five-point Likert-type scales anchored by 1 = strongly disagree and $5=$ strongly agree. In Section C, Likert-type scales were also used for presenting the response options but were anchored by $1=$ much better than industry average and $5=$ much worse than industry average. A copy of the measurement scales used in sections B and C is provided in Appendix 1.

\section{Statistical analysis}

In this study, data were analysed by using descriptive statistics, correlation analysis and regression analysis. The Statistical Package for the Social Sciences (SPSS version 23.0) was used as the statistical analysis tool. Descriptive statistics were used in the analysis of the demographic details of respondents. The Pearson correlation coefficient was used to assess the association between the supply chain management problems faced by the food processing industry and their influence on business performance. Regression analysis was performed to identify the variables that predicted or provided the best explanation for the portion of the total variance in the scores of the dependent variables.

\section{Scale accuracy}

Various measures were applied to ensure that measurement scales used in the study were reliable and valid. Reliability, which refers to the extent to which test scores are free of measurement error (Salkind 2012), was tested by using the Cronbach's alpha $(\alpha)$ coefficient. As prescribed by Tavakol and Dennick (2011), measurement scales should have attained Cronbach's alpha values greater than 0.7 in order to be classified as reliable. The Cronbach's alpha values for the measurement scales used in the study ranged between 0.721 and 0.884 (refer to Table 1), which were acceptable because they fell above the recommended minimum threshold.

Validity is the degree to which evidence and theory support the interpretations of test scores (Root, Fellows \& Hancock 2013). Four types of validities, namely face, content, convergent and predictive validities, were considered. Face validity was ascertained through an assessment of the questionnaire by senior faculty members at a South African university of technology whose research focus area is supply chain management to ensure that all scales measured exactly the problems to supply chain management as well as business performance and therefore led to accurate results. Content validity was established through pilot testing the questionnaire. A pilot test was conducted, by using 50 respondents who were selected by using the convenience sampling technique suggested by Collins (2003). These respondents did not participate in the main survey. Feedback was obtained from the faculty experts and the pilot sample was used to make improvements, which made the final questionnaire clearer and more useful. Convergent validity was measured by using Pearson correlation coefficients (refer to Table 2). There were significant correlations existing between the different constructs, thereby implying that convergent validity was acceptable. Predictive validity was tested through regression analysis, which showed significant relationships between dependent and independent variables (refer to Table 3). This confirms that predictive validity was adequate in this study.

\section{Research results}

This section discusses the demographic details of respondents, factor analysis, correlation analysis and regression analysis.

\section{Demographic details of respondents}

The demographic details about these respondents are presented in Table 4.

TABLE 1: Extracted constructs and operational definitions.

\begin{tabular}{|c|c|c|c|c|}
\hline Name of factor & $\begin{array}{l}\text { No. of } \\
\text { items }\end{array}$ & $\begin{array}{c}\text { Percentage of } \\
\text { variance explained }\end{array}$ & $\begin{array}{l}\text { Reliability } \\
(\alpha)\end{array}$ & Operational definition \\
\hline $\begin{array}{l}\text { Human resource } \\
\text { management }\end{array}$ & 4 & 9.004 & 0.721 & $\begin{array}{l}\text { A business function that encompasses the duties and tasks related to the people, their acquisition, } \\
\text { selection, training and other activities that ensure the motivation of employees (Jackson \& Mathis 2012) }\end{array}$ \\
\hline Technology & 4 & 14.017 & 0.884 & $\begin{array}{l}\text { The practical manipulation of knowledge or technical processes and methods especially in a particular } \\
\text { area (Zhu, Sarkis \& Lai 2012) }\end{array}$ \\
\hline Facilities & 5 & 1.643 & 0.788 & The physical structures that enable businesses to run smoothly (Redlein, Loeschl \& Fuke 2015) \\
\hline $\begin{array}{l}\text { Supplier relationship } \\
\text { management }\end{array}$ & 5 & 3.954 & 0.763 & $\begin{array}{l}\text { A comprehensive approach to creating closer, more collaborative relationships with key suppliers in order } \\
\text { to reduce risk and increase performance (Tangpong et al. 2015) }\end{array}$ \\
\hline $\begin{array}{l}\text { Customer relationship } \\
\text { management }\end{array}$ & 5 & 11.341 & 0.811 & Thorough management of customers to create and increase value across the supply chain (Buttle 2012) \\
\hline Regulatory factors & 3 & 1.487 & 0.765 & Laws governing how business should behave (Cambini et al. 2016) \\
\hline $\begin{array}{l}\text { Logistics and } \\
\text { transportation }\end{array}$ & 4 & 4.322 & 0.773 & $\begin{array}{l}\text { Processes that effectively design, implement and control the circulation and storing of goods, services } \\
\text { and data from origin to destination to satisfy needs of customers (Cozzolino 2012) }\end{array}$ \\
\hline
\end{tabular}

Source: Authors' own work 
TABLE 2: Correlations: Supply chain management problems and business performance.

\begin{tabular}{|c|c|c|c|c|c|c|c|c|}
\hline Factors & HRM & Tech & Facilities & SRM & CRM & $\mathbf{R F}$ & $\mathrm{L} \& \mathrm{~T}$ & Bus. performance \\
\hline HRM & 1.000 & - & - & - & - & - & - & - \\
\hline Technology & $0.545^{*}$ & 1.000 & - & - & - & - & - & - \\
\hline Facilities & $0.374 *$ & $0.423 *$ & 1.000 & - & - & - & - & - \\
\hline SRM & $0.404 *$ & $0.421 *$ & $0.417^{*}$ & 1.000 & - & - & - & - \\
\hline CRM & $0.512 *$ & $0.546 *$ & $0.549 *$ & $0.601 *$ & 1.000 & - & - & - \\
\hline Regulatory factors & $0.453 *$ & $0.368 *$ & $0.283 *$ & $0.388^{*}$ & $0.445^{*}$ & 1.000 & - & - \\
\hline Logistics and transport & $0.537 *$ & $0.424 *$ & $0.389 *$ & $0.541^{*}$ & $0.594 *$ & $0.491 *$ & 1.000 & - \\
\hline Bus. performance & -0.497 & -0.572 & -0.296 & -0.253 & -0.564 & -0.106 & -0.332 & 1.000 \\
\hline
\end{tabular}

Source: Authors' own work

HRM, human resource management; Tech, technology; SRM, supplier relationship management; CRM, customer relationship management; RF, regulatory factors; L \& T, Logistics and transport. $N=303$.

*, Correlation is significant at the 0.01 level (two-tailed).

Small, $r$ 0.10-0.29; medium, $r=0.30-0.49$; large, $r=0.50-1.0$

TABLE 3: Regression model: Supply chain management problems and business performance.

\begin{tabular}{|c|c|c|c|c|c|}
\hline \multirow{2}{*}{$\begin{array}{l}\text { Independent constructs: Supply chain } \\
\text { management problems }\end{array}$} & \multicolumn{3}{|c|}{ Dependent construct: Business performance } & \multirow[t]{2}{*}{ Tol } & \multirow[t]{2}{*}{ VIF } \\
\hline & Beta & $T$ & Sig & & \\
\hline Human resources & -0.464 & -1.680 & $0.047^{*}$ & 0.702 & 1.641 \\
\hline Technology & -0.569 & -2.197 & $0.014 *$ & 0.844 & 1.283 \\
\hline Facilities & -0.260 & -2.685 & $0.003^{*}$ & 0.752 & 1.208 \\
\hline Supplier relationship management & -0.201 & -2.924 & $0.002 *$ & 0.722 & 1.375 \\
\hline Customer relationship management & -0.553 & -1.711 & $0.044 *$ & 0.916 & 1.164 \\
\hline Regulatory factors & -0.041 & -1.032 & 0.151 & 0.788 & 1.424 \\
\hline Logistics and transport & -0.302 & -1.654 & $0.049 *$ & 0.841 & 1.382 \\
\hline
\end{tabular}

\section{Logistics and transport}

Source: Authors' own work

Tol, tolerance; VIF, variance inflation factor.

$R, 0.568 ; R$-squared, 0.471 ; adjusted $R$-squared, $0.474 ; *$, Sig. $p<0.05$.

TABLE 4: Demographic details of respondents.

\begin{tabular}{|c|c|c|c|}
\hline Variables & Categories & $N$ & $\%$ \\
\hline \multirow[t]{2}{*}{ Gender } & Male & 190 & 62.8 \\
\hline & Female & 113 & 37.2 \\
\hline \multirow[t]{5}{*}{ Age } & $18-25$ & 34 & 11.2 \\
\hline & $26-35$ & 147 & 48.5 \\
\hline & $36-45$ & 99 & 32.7 \\
\hline & $46-55$ & 20 & 6.6 \\
\hline & $56+$ & 3 & 1.0 \\
\hline \multirow[t]{4}{*}{ Race } & Black & 173 & 57.1 \\
\hline & White & 64 & 21.1 \\
\hline & Indian & 35 & 11.6 \\
\hline & Mixed race & 31 & 10.2 \\
\hline \multirow{4}{*}{$\begin{array}{l}\text { Post-matric } \\
\text { academic } \\
\text { qualifications }\end{array}$} & Certificate & 76 & 25.1 \\
\hline & Diploma & 100 & 33.0 \\
\hline & Degree & 114 & 37.6 \\
\hline & Postgraduate & 13 & 4.3 \\
\hline \multirow{4}{*}{$\begin{array}{l}\text { Employment } \\
\text { period }\end{array}$} & Under 2 years & 15 & 5.0 \\
\hline & $2-5$ years & 110 & 36.3 \\
\hline & $6-10$ years & 116 & 38.3 \\
\hline & 10 years + & 62 & 20.4 \\
\hline \multirow{5}{*}{$\begin{array}{l}\text { Occupational } \\
\text { position }\end{array}$} & Executive & 7 & 2.3 \\
\hline & Senior manager & 13 & 4.3 \\
\hline & Junior manager or supervisor & 53 & 17.5 \\
\hline & Specialist & 132 & 43.6 \\
\hline & Operator or clerk & 98 & 32.3 \\
\hline
\end{tabular}

Source: Authors' own work

\section{Factor analysis}

Factor analysis was performed to check the underlying problems of supply chain management in the food processing industry. Prior to factor analysis, a Bartlett's test of sphericity was computed, which was significant at $p<0.001$, thereby inferring that the collected data were suitable for factor analysis (Tabachnick \& Fidell 2007). The Kaiser Meyer Olkin measure of sampling adequacy was 0.821 , which further supports that the data were suitable for factor analysis (Kaiser 1974). The extraction of factors was achieved through the application of three criteria, namely the percentage of variance explained, the scree plot and the Guttman rule, of which the last one suggests that all factors with eigenvalues greater than 1 should be retained (Guttman 1954). In the process, some scale items were eliminated either because of cross-loadings or low factor loadings less than 0.5 , as suggested by Costello and Osborne (2005). Items that have cross-loadings should be removed because they relate with more than one factor while items with low factor loadings below 0.5 do not relate or correlate with other items, and hence are unimportant (Warne \& Larsen 2014). Items eliminated included two questions from the human resource management scale, three questions from the supplier relationship management scale, two questions from the regulatory factors scale and three questions from the logistics and transportation scale. The factor analysis procedure resulted in the extraction of seven factors representing problems to supply chain management in the food processing industry. The names of these factors and other details are presented in Table 1.

As indicated in Table 1, the seven factors extracted were labelled human resource management, technology, facilities, supplier relationship management, customer relationship management, regulatory factors, and logistics and transportation. The seven factors contributed to $45.77 \%$ of the total variance. This result depicts that the seven factors extracted in this study accounted for nearly $46 \%$ of the problems to supply 
chain management in the food processing industry. The remaining $54 \%$ of the problems to supply chain management are accounted for by other extraneous factors that were not considered in this study. Among the extracted factors, technology contributed the highest percentage of variance (14.017) and regulatory factors contributed the least percentage of variance (1.487).

\section{Correlation analysis}

In this study, correlations were intended to measure the degree and direction of association occurring between constructs. The Pearson's correlation coefficient, which assesses the degree to which quantitative constructs are linearly related in a sample (Nikolić et al. 2012), was used to determine the association between supply chain management problems and business performance. In the ensuing discussion, the resultant correlations were indicated by the prefix ' $r$ ' - where the degree of correlation was expressed by a value of the coefficient (Katz 2006). The results of the Pearson's correlation analysis are presented in Table 2.

Interfactor correlations show the associations among the constructs, with the purpose to elaborate on how a relationship may occur between the constructs under consideration (Genest \& Nešlehová 2009). In this study, positive interfactor correlations were observed between the seven supply chain management problems. The strongest correlation occurred between SRM and CRM $(r=0.601$; $p<0.01$ ) while the weakest correlation was between facilities and regulatory factors $(r=0.283 ; p<0.01)$. This indicates that when one supply chain management problem considered in this study either increases or decreases, the other supply chain management problems also increase or decrease correspondingly.

\section{Regression analysis}

Regression analysis was used as a tool for determining whether each of the independent constructs predicted business performance, which is beyond the limits of the correlation analysis (Armstrong, Eperjesi \& Gilmartin 2005). Table 3 presents the regression model summary for supply chain management problems and business performance in the food processing industry.

In the regression model (Table 3), supply chain management problems (adjusted $R^{2}=0.474$ ) explained approximately $47 \%$ of the variance (problems) that impact business performance in the food processing industry. This depicts that $53 \%$ of the variance is explained either by other problems that were not considered in this study or by the items discarded in the factor analysis. Tolerance and the variance inflation factor (VIF) values were used to determine the effects of multicollinearity in this study. Multicollinearity occurs when two or more of the independent constructs are correlated, leading to flawed predictions concerning the independent and dependent constructs (Kock \& Lynn 2012). Tolerance values measure the strength of the association (influence) between one independent construct and the other independent construct and should be $T>0.5$ ( $\mathrm{O}^{\prime}$ Brien 2007). VIF is a measure of the impact of collinearity among the constructs under consideration in a regression model and should ideally be VIF < 10 (O'Brien 2007). As shown in Table 3 , tolerance and VIF values for all independent constructs were within recommended thresholds and did not indicate any significant multicollinearity risks.

\section{Ethical considerations}

Several ethical considerations were applied during the study. Permission to collect data was requested and granted by each business before data were collected. Each respondent signed a consent form, which made it clear to them that participation was voluntary and discrimination would not take place against those that did not intend to participate. The nature and purpose of the study were discussed with the respondents, and an information sheet was handed out for each questionnaire. They were also assured that the results of the study would be made available to them once the study was completed. Respondents were not pressured to participate and were given a period of two weeks, which was adequate to complete the survey questionnaire. Throughout the study, the identities of respondents were safeguarded and remained anonymous. No incentives were given to respondents for participating in the survey.

\section{Discussion}

This section focuses on the individual relationships between the seven supply chain management problems and business performance.

\section{Human resource management and business performance}

The concept of human resources management defines business practices dealing with elements that include the recruitment, motivation, training and management of its workforce (Zhang, Wan \& Jia 2009). Table 3 reveals that there was a moderate negative correlation relationship between human resources management-related problems and business performance $(r=-0.497 ; p<0.01)$. In the regression analysis, human resource management problems were statistically significant in predicting business performance ( $b=-0.464 ; t=-1.680 ; p=0.047)$. The result of the correlation analysis implies that if human resource-related problems increase, business performance will decrease, and vice versa. Likewise, the negative beta value in the regression analysis implies that human resource management problems have the effect of reducing business performance. Similar results were also obtained in a study by Paul and Anantharaman (2003) who concluded that increasing problems in human resources management can negatively affect business performance across different industries. Moreover, another study by Van de Voorde, Paauwe and Van Veldhoven (2010) concluded that there is a negative relationship between human resource problems and business performance. This confirms that problems in human resource management can be detrimental to the success of a business. 
Businesses have become increasingly aware of the importance of human resource management as a source of competitive advantage (Guthrie \& Messersmith 2010). An educated, informed and skilled human resource base is fundamental to ensure that business performance targets are achieved (Kepe \& Tessaro 2014). Problems may arise in the human resource function and may include the shortage of skilled employees, labour unrest, the lack of effective human resource systems, employee dissatisfaction and mismanagement, among others (Cooke 2013). When problems develop in these and other human resource areas, employees may become demoralised and may pass on their frustration to customers, leading to loss of customers (Bouville \& Alis 2014). Unhappy employees may also sabotage the business by engaging in counterproductive behaviours such as absenteeism, go-slows and theft, leading to low productivity (Darwish \& Sing 2013). In addition, human resource-related problems may lead to poor-quality work, which may trigger customer dissatisfaction, legal disputes and decreasing profits (Jackson, Schuler \& Jiang 2014). Groenmeyer (2013) adds that the lack of measures to improve the skills and knowledge of human resources, such as the level of education, compensation and training, represents major challenges to the development of the South African food processing industry. Thus, the food processing industry is not immune to the adverse effects of such human resource problems, and measures have to be taken to ensure that their effects are minimised.

\section{Technology and business performance}

A strong negative correlation was observed between technology-related problems and business performance $(r=-0.572 ; p<0.01)$. Analysis of the regression model shows that technology-related problems were statistically significant in predicting business performance $(\mathrm{b}=-0.569 ; t=-2.197$; $p=0.014)$. The negative correlation and beta imply that the existence of technology-related problems has the effect of reducing the performance of businesses in the food processing industry. In support, the results of studies conducted by Tavitiyaman, Zhang and Qu (2011) and Forsman and Temel (2011) showed a strong negative relationship occurring between technology-related problems and business performance. These results were connected to the decrease in both market share and profits by businesses experiencing technology-related problems, as they were unable to match the performance of their technologically advanced competitors. Therefore, as argued by Lewis, Hodge, Gamage and Whittaker (2012), businesses must be aware of technological developments within their industries if they are to be effectively involved in new process, product and service improvements. This awareness enables such businesses to operate in constantly dynamic markets in which superior business performance is necessary for survival.

The technology-related problems factor emerged as the strongest predictor of business performance compared to other problems because it scored the highest beta value. Perhaps this result can be linked to the important role of technology in today's business environment. As mentioned by Alodeh (2011) technology enables businesses to try new ideas, manipulate the opportunities that are available during market access and gain competitive advantage. New technological developments present new demands to businesses and provide new possibilities for developing or improving market activities as well as products (Brodbeck, Rigoni \& Hoppen 2009). The ability to adopt new technologies also has direct consequences on the ability to compete in an industry (Moore 2012). The values created by technology management are often exhibited through new ways of doing things or creating new products and processes that contribute to business success (Avramović 2010). The adoption of technology can enable the business to transform its internal capabilities by making the business more adaptive and aligned with current or future innovations to increase market share and enhance competitiveness (Chebrolu \& Ness 2013). It could be that this extensive impact in numerous areas of business gives technology an edge, thereby making its problems more significant compared to the other six problems considered in this study. It is therefore important for the food processing industry to develop a business environment that supports and promotes technology if success is to be achieved.

\section{Facilities and business performance}

A weak negative correlation $(r=-0.296 ; p<0.01)$ existed between facilities-related problems and business performance. This result implies that as problems in facilities increase, there will be a decline in business performance and vice versa. Further analysis of the outcomes of the regression analysis shows that facilities-related problems were statistically significant in predicting business performance $(b=-0.260$; $t=-2.685 ; p=0.003)$. The negative beta result demonstrates that problems related to facilities exert a negative impact on business performance in the food supply chain.

Poor facilities are harmful to the success of a business. According to Scupola (2012), the absence of suitable facilities could lead to extreme resource investments. Generally, the lack of state-of-the-art facilities at organisational level contributes to poor business performance and could hamper the sourcing and supply processes of a business (Tucker \& Pitt 2009). Scupola (2012) reiterates that facilities are considered to be among the crucial linkages between a business and its markets, which can have the potential to impact on the business' revenues and overall effectiveness. Poor design and layout of facilities may lead to health and safety issues, leading to occupational hazards that may negatively affect the well-being of employees (Junghans 2011). Uncleanliness within facilities, especially in the food industry can lead to the flight of customers as they avoid the risk of contracting food-borne diseases (Eriksson, Strid \& Hansson 2012). Likewise, the location of a facility that is considered inconvenient by customers may lead to decreased business (Kimelberg \& Williams 2013). If the technology and equipment used within facilities is obsolete, the quality of the products decreases and maintenance costs are likely to be high, which is detrimental to business success (Elmualim, 
Vallie \& Kwawu 2012). Ineffective management of waste within facilities can lead to occupational accidents and censure by regulatory authorities (Collins \& Junghans 2015). Hence, measures must be taken to deal with problems related to facilities at every level of the economy. This is essential for the food processing industry as there could be distinctive issues involved that may obviously affect business performance.

\section{Supplier relationship management and business performance}

A weak negative correlation existed between the supplierrelated management problems and business performance $(r=-0.253 ; p<0.01)$. This result illustrates that when problems related to supplier relationship management increase, business performance will decrease. Regression analysis indicates that supplier relationship management problems were statistically significant in predicting business performance $(b=-0.201$; $t=-2.924 ; p=0.002)$. The negative beta shows that the existence of problems in supplier relationship management leads to poor business performance.

In the background of dynamic global markets, competition and supply chains and fast-changing industry practices, businesses are now confronting new problems (Gadde, Håkansson \& Persson 2010). Supply chains are becoming increasingly complex and dynamic while distribution channels are expanding with an increasing dependence on outsourced manufacturing and logistics (Kosgei \& Gitau 2016). The need to improve supplier-buyer relationships has become more apparent in the pursuit to achieve operational excellence (Lockström et al. 2010). Burnet (2012) suggests that the understanding of supplier relationship management leads to the development of procurement strategies that reduce costs, make procurement predictable and repeatable, clarify supplier partnership decisions and provide control over suppliers in negotiations. Msimangira and Venkatraman (2014) argue that businesses cannot just rely on their internal resources and capabilities to achieve performance. Rather, they should realise the need to develop clear supplier development programmes which will allow businesses to engage in activities that improve the performance of suppliers, which result in better performance. Thus, the lessening of problems related to supplier management in the food processing industry is important for improving competitive performance that leads to attainment of optimum business performance.

\section{Customer relationship management and business performance}

A strong negative correlation existed between customer relationship management problems and business performance $(r=-0.564 ; p<0.01)$. This implies that when problems related to customer relationship management increase, business performance will decrease. Conversely, when those problems decrease, business performance increases. In the regression analysis, customer relationship management problems emerged as statistically significant in predicting business performance $(b=-0.553 ; t=-1.711$; $p=0.044)$. The negative beta result indicates that the existence of these problems causes a decline in business performance.

Effective management of customer relationships is one of the most important problems in business competition. Businesses require some information about their customers, their expectations and needs and how to meet their requirements (Wang et al. 2010). Understanding how businesses can profit from their customer relationships is important for both marketing practitioners and academics (Akroush et al. 2011). According to Dutu and Halmajan (2011), businesses that have adopted customer relationship management as a core strategy are likely to grow at a faster speed than other businesses in the same industry that have not done so. Kubi and Doku (2010) state that effective customer relationship management creates superior value for the business and the customer by incorporating marketing, sales, customer service and the supply chain processes of the business to achieve greater efficiencies. Shwu and Chien (2012) highlight that businesses that focus on customer relationship management exceed customer expectations and increase the level of customers' satisfaction, leading to customer loyalty as shown through repeat sales. Wang and Feng (2012) further posit that customer relationship management indirectly affects business performance by increasing efficiency and cutting costs. This makes it important for businesses in the food processing industry to focus on mitigating any problems related to customer relationship management to realise these benefits.

\section{Regulatory factors and business performance}

Table 3 shows that there was a small negative correlation between problems related to regulatory factors and business performance $(r=-0.106 ; p<0.01)$. This result implies that if problems related to regulatory factors increase, business performance decreases. However, business performance is likely to increase whenever there is a decrease in problems related to regulation. The analysis of the outcomes of the regression model shows that regulatory problems were not statistically significant in predicting business performance ( $b=-0.041 ; t=-1.032 ; p=0.151)$. This result indicates that business performance is not linked to regulatory problems. The beta is very small (almost zero), indicating that the impact of regulatory problems on business performance is virtually unimportant in this case.

The results obtained in this study contradict previous research studies (Adeoye 2012; Amoako-Gyampah \& Acquaah 2008; De Jong, Phan \& Van Ees 2011; Ren 2010; Tu 2012), which concluded that regulatory problems negatively affect business performance. It is conceivable that the lack of an association between regulatory factors and business performance could be attributed to a lacklustre approach towards some regulatory aspects within the food processing industry in South Africa. Available evidence points to severe malpractices by businesses in this industry, many of which are only discovered either accidentally or after much damage 
has been done. For example, a widely publicised study by Cawthorn, Steinman and Hoffman (2013) at Stellenbosch University found that mislabelling of processed meat was prevalent in the South African meat industry. Their study found horse, donkey, goat, water buffalo and soya in some samples of fraudulently packed meat products. In addition, there have been several discoveries involving tap water being bottled as spring or natural water and sold to unsuspecting consumers (South African National Bottled Water Association 2016). In addition, South Africa imports many food products, both processed and unprocessed, from other countries. For instance, the country imported USD7.0 billion worth of agricultural and food products in 2015 (International Trade Administration 2016). This importation of large volumes of food products creates further regulatory problems in that different standards are used in the countries involved. In line with this, in March 2017 South Africa banned the importation of meat products from Brazil, citing a scandal over rotten meat (South African Poultry Association 2017). However, this decision was only taken after other countries had long implemented the same decision, which implies that many people in South Africa had for some time been consuming the affected meat products. Finally, it is possible that the available regulations are generally unfavourable to businesses in the food processing industry, leading to various problems as businesses struggle to meet them. These issues, as well as several others within the same industry, point to entrenched regulatory problems in the industry. It could be that regulatory authorities in the country are failing to control the business practices in the food processing industry. Therefore, the industry itself is responding to this lack of regulation, hence the view that regulation problems do not necessarily influence business performance.

\section{Logistics and transportation and business performance}

A moderate negative correlation $(r=-0.332 ; p<0.01)$ emerged between logistics and transportation problems. This result implies that when problems related to logistics and transportation increase, business performance also decreases. However, business performance will increase when the intensity of such problems is reduced. Regression analysis shows that problems associated with logistics and transportation were statistically significant in predicting business performance $(b=-0.302 ; t=-1.654 ; p=0.049)$. The negative beta indicates an inverse relationship between the two variables, such that business performance is likely to be negative where more logistics and transportation problems exist.

Logistics and transportation are part of supply chain management dealing with the planning, implementation and control of goods flow and information between production and consumption to meet customer needs (Perry 2012). Different modes of transportation such as rail, road, water, air, pipeline, cable and space can be used to transmit the goods from one point to another (Karia \& Wong 2013). As confirmed by Sukati, Abdul Hamid and Baharun (2013), the performance of logistics and transportation processes has an impact on customer service, inventory levels and cost optimisation that lead to better business performance. Chinomona (2013) pronounces that the management of transportation and logistics has been a critical concern for manufacturers, distributors and third-party logistics industries in their search for achieving a lean, agile and efficient supply chain. Businesses are looking at logistics to improve customer experiences and create differentiation as today's demanding customers require not just fulfilment of requirements, but also expect to receive their products or services when and where they require and at a good price (Esper, Fugate \& DavisSramek 2007; Tseng, Taylor \& Yue 2005). Lu and Yang (2010) proposed a framework for future supply chain research that included transportation and logistics capabilities as the link between business structure and performance. Logistics and transportation strategies support integration of business processes such as purchasing, manufacturing, selling and logistics throughout the chain to provide optimum value to the ultimate customer (Kamel, Vinod \& Uma 2010). Thus, efforts aimed at alleviating problems related to the logistics and transportation function in the food processing industry should lead to better business performance.

\section{Conclusions and managerial implications}

The aim of this study was to investigate supply chain management problems and their influence on business performance in the food processing industry in South Africa. Literature emphasised that it is important to study supply chain management problems in order to understand their origin and generate approaches to both avoid them and reduce their negative effects on business performance. It further emerged in the literature that although the food processing industry is an important contributor to the South African economy, it faces numerous problems which have to be overcome. Seven problems, namely human resources management, technology, facilities, supplier relationship management, customer relationship management, regulatory factors, and logistics and transportation were identified through the factor analysis procedure. Application of the Pearson correlation analysis revealed that all seven problems were negatively associated with business performance. In the regression analysis, all seven supply chain management problems, except for regulatory problems, predicted business performance. Technology-related problems emerged as the strongest challenge predicting business performance. It is therefore concluded that supply chain management problems exert a negative influence on business performance in the food processing industry.

The results of the study have several theoretical and managerial implications. Theoretically, it provides further evidence of the importance of supply chain management as a driver of business performance in food processing industries within developing countries. Given the need to continuously grow the body of literature on supply chain management in specific sectors of the economies in developing countries, the study plays a vital role in reducing such gaps, especially in 
the food supply chain. The overall managerial implication of this study is that business performance in the food industry may be improved by, among other things, decreasing the intensity of supply chain management problems. In terms of human resources, there is a shortage of supply chain professionals in South Africa (Department of Higher Education 2016). In view of this, there is a need to focus on a nationwide campaign for young people to obtain qualifications and competency within the field of supply chain management. However, at business level, it is important that competent supply chain professionals be recruited. Once they are recruited, further and regular training and development of these professionals is essential to update their knowledge, skills and proficiency. To lessen technologyrelated problems, the faster adoption of disruptive technologies, regular maintenance of key technologies as well as integration of the benefits of technology into all business operations to remain competitive is required. International Organisation for Standardisation (ISO) standards as well as sustainability or green supply chain management systems could be implemented to counter problems associated with facilities management.

To mitigate supplier relationship management problems, regular meetings and even workshops should be organised to discuss how buyer-supplier interactions can be improved and how the changes can be handled. In terms of customer relationship management, regular and consistent communication (for example, through social media, marketing campaigns, company websites, technical support call facilities) with customers is essential to understand their needs and how to adapt the products to these needs. Compliance with government legislation and policies regarding issues such as taxes, food safety standards, labour laws, environmental laws and business ownership, among others, could be used to counter the effects of regulationrelated problems. The effectiveness of logistics and transport mechanisms may be improved by considering the utilisation of proper load and delivery route planning as well as outsourcing transportation to expert businesses when this is regarded as a non-core function.

\section{Limitations and suggestions for further research}

Some limitations of this study should be highlighted so that they can be addressed in future. The study is limited in that its results were restricted to a sample size of 303 respondents based in a single province, Gauteng. This negatively affects the generalisability of the study to other regions. Another limitation is found in its use of measurement scales adapted from other studies not originally intended for the food processing industry, which could have adversely influenced the validity of the results. However, as mentioned before, tests for validity were conducted and proved to be satisfactory. The use of the convenience sampling method may also have affected the study through sampling bias. To control sampling bias, efforts were made to ensure that data were collected from different sizes of businesses located in various regions of Gauteng Province.
The study has several implications for future research. First, similar studies can be conducted in different locations or regions in South Africa because the views of respondents are bound to differ depending on their environment. Second, the study can also be replicated in other industry segments apart from the food processing industry. Third, more robust statistical approaches such as structural equation modelling could be used in future studies because the study is multifactorial in nature, involving numerous independent variables. A longitudinal approach to this study could reveal any changes regarding the problems to supply chain management and their influence on business performance in different time periods. Because only seven supply chain management problems were realised, similar studies could be conducted at a broader scope with the intention of exploring other supply chain management problems that were excluded in this study.

\section{Acknowledgements}

The authors would like to thank the reviewers of this article who provided important input which improved the article in various ways. The authors further thank participating food processing firms in Gauteng Province for granting permission for the collection of data. Gratitude is also directed to the Faculty of Management Sciences at Vaal University of Technology in South Africa for its role in the administrative processes leading to the completion of this research and for funding the publication fees.

\section{Competing interests}

The authors declare that they have no competing interests.

\section{Authors' contributions}

C.A.N.N. was responsible for developing the research idea, identifying the research gaps, drafting the questionnaire and collecting the data. C.M. was responsible for writing the sections of the article.

\section{References}

Adebanjo, D., 2011, 'Understanding demand management challenges in intermediary food trading: A case study', Supply Chain Management: An International Journa 14(3), 224-233. https://doi.org/10.1108/13598540910954566

Adeoye, A.A., 2012, 'Impacts of external business environment on organisational performance in the food and beverage industry in Nigeria', British Journal of Arts and Social Sciences 6(2), 194-201.

Aguinis, H., Joo, H. \& Gottfredson, R., 2011, 'Why we hate performance management and why we should love it', Business Horizons 54, 503-507. https://doi.org/ 10.1016/j.bushor.2011.06.001

Akroush, M.N., Dahiyat, S.E., Gharaibeh, H.S. \& Abu-Lail, B.N., 2011, 'Customer relationship management implementation: An investigation of a scale's generalizability and its relationship with business performance in a developing country context', International Journal of Commerce and Management 21(2), country context', International Journal of Commerce and
158-191. https://doi.org/10.1108/10569211111144355

Alodeh, H., 2011, 'The current situation of supply chain management and technology structure at Al-Hassan Industrial Estate in Jordan', master's dissertation, The College of Graduate and Professional Studies, Indiana State University, viewed 06 College of Graduate and Professional Studies, Indiana State University, viewed 06
July 2015, from scholars.indstate.edu/xmlui/bitstream/handle/10484/.../Alodeh, $\% 20$ Mahmoud.PDF?...2

Amoako-Gyampah, K. \& Acquaah, M., 2008, 'Manufacturing strategy, competitive strategy and firm performance: An empirical study in a developing economy environment', International Journal of Production Economics 111(2), 575-592. https://doi.org/10.1016/j.ijpe.2007.02.030

Andersen, P.H. \& Rask, M., 2013, 'Supply chain management: New organisational practices for changing procurement realities', Journal of Purchasing \& Supply Management 9(3), 83-96. 
Armstrong, R.A., Eperjesi, F. \& Gilmartin, B., 2005, 'The use of correlation and regression methods in optometry', Clinical and Experimental Optometry 88(2), 81-88.

Avramović, M., 2010, 'Information communication technology in the function of improvement of competitive position of tourist destination', Economics and Organization 7(2), 209-217.

Babbie, E. \& Mouton, J., 2012, The practice of social research, Oxford University Press, Cape Town.

Bac, U. \& Erkan, T.E., 2011, 'A model to evaluate supply chain performance and flexibility', African Journal of Business Management 5(11), 4263-4271.

Bharthvajan, R., 2014, 'Human resource management and supply chain management intersection', International Journal of Innovative Research in Science, Engineering and Technology 3(3), 10163-10167.

Bonner, J. \& Calantone, R.J., 2005, 'Buyer attentiveness in buyer-supplier relationships' Industrial Marketing Management 34(1), 53-61. https://doi.org/10.1016/j. indmarman.2004.07.003

Bouville, G. \& Alis, D., 2014, 'The effects of lean organizational practices on employees' attitudes and workers' health: Evidence from France', International Journal of Human Resource Management 25(21), 3016-3037. https://doi.org/10.1080/0958 5192.2014.951950

Brik, A.B., Rettab, B. \& Mellahi, K., 2011, 'Market orientation, corporate social responsibility and business performance', Journal of Business Ethics 99(3), 307324. https://doi.org/10.1007/s10551-010-0658-z

Brodbeck, N., Rigoni, E. \& Hoppen, N., 2009, 'Strategic alignment maturity between business and information technology in southern Brazil', Journal of Global Information Technology Management 12(2), 5-32. https://doi.org/10.1080/1097 198X.2009.10856489

Burnet, K., 2012, 'Supplier relationships in business briefing', Global Purchasing and Supply Chain Strategies 18(4), 36-45.

Buttle, F., 2012, Customer relationship management: Concepts and technologies, 2nd edn., Butterworth-Heinemann, Oxford

Cambini, C., Meletiou, A., Bompard, E. \& Masera, M., 2016, 'Market and regulatory factors influencing smart-grid investment in Europe: Evidence from pilot projects and implications for reform', Utilities Policy 40, 36-47. https://doi.org/10.1016/j. jup.2016.03.003

Carter, C.R. \& Easton, P.L., 2011, 'Sustainable supply chain management: Evolution and future directions of logistics management distribution', International Journa of Physical Distribution \& Logistics Management 41, 46-62. https://doi. org/10.1108/09600031111101420

Cassim, B., 2010, 'Food and beverage marketing to children in South Africa: Mapping the terrain', South African Journal Clinical Nutrition 23, 181-185. https://doi.org/ 10.1080/16070658.2010.11734335

Cawthorn, D.M., Steinman, H.A. \& Hoffman, L.C., 2013, 'A high incidence of specie substitution and mislabelling detected in meat products sold in South Africa', Food Control 32, 440-449. https://doi.org/10.1016/j.foodcont.2013.01.008

Chebrolu, S.B. \& Ness, L., 2013, 'How does alignment of business and IT strategies impact aspects of IT effectiveness?', International Journal of Applied Managemen and Technology 12(1), 1-15.

Chinomona, R., 2013, 'The fostering role of information technology on SMEs' strategic purchasing, logistics integration and business performance: Zimbabwe distribution channels', African Journal of Business 17(1), 76-97.

Choi, T.Y. \& Harley, J.I., 1996, 'An exploration of supplier selection practices across the supply chain', Journal of Operations Management 14(4), 333-343. https://doi. org/10.1016/S0272-6963(96)00091-5

Chow, W.S., Madu, C.N., Kuei, CH., Lu, M.H., Lin, C. \& Tseng, H., 2010, 'Supply chain management in the US and Taiwan: An empirical study', The International Journa of Management Science 36, 665-679.

Chung-Kee, C. \& Chuwonganant, C., 2014, 'Uncertainty, market structure, and liquidity', Journal of Financial Economics 11, 476-499. https://doi.org/10.1016/j. jineco.2014.05.008

Cloete, J M., Lenka, L. Marais, A. \& Venter, A., 2012, 'The role of urban agriculture in addressing household poverty and food security: The case of South Africa', pape prepared for the Global Development Network Project, Institutional Capacity Strengthening of African Public Policy Institutes to Support Inclusive Growth and the MDGs, 20-30th April, Pretoria, South Africa.

Collins, D., 2003, 'Pretesting survey instruments: An overview of cognitive methods', Quality of Life Research 12, 229-238. https://doi.org/10.1023/A:1023254226592

Collins, D. \& Junghans, A., 2015, 'Sustainable facilities management and green leasing: The company strategic approach', Procedia Economics and Finance 21, 128-136. https://doi.org/10.1016/S2212-5671(15)00159-8

Coltman, T., Devinney, T.M. \& Midgley, D.F., 2011, 'Customer relationship management and firm performance', Journal of Information Technology 26(3), 205-219. https://doi.org/10.1057/jit.2010.39

Cooke, F.L., 2013, 'Human resource development and innovation in China: State HRD policies, organizational practices, and research opportunities', Journal Chinese Human Resource Management 4(2), 144-150. https://doi.org/10.1108/JCHRM05-2013-0016

Costello, A.B. \& Osborne, J.W., 2005, 'Best practices in exploratory factor analysis: Four recommendations for getting the most from your analysis', Practical Assessment, Research and Evaluation 10(7), 1-9.

Council of Supply Chain Management Professionals, 2010, Supply chain management, viewed 02 July 2017, from http://www.cscmp.org

Cousins, B. \& Scoones, I., 2014, 'Contested paradigms of "viability" in redistributive land reform: Perspectives from Southern Africa', The Journal of Peasant Studies 37(1), 31-66. https://doi.org/10.1080/03066150903498739
Cozzolino, A., 2012, Humanitarian logistics and supply chain management, Springer, Berlin.

Cronin, C., 2015, The organic food industry: An analysis of supply and demand via aggregate prices, Summer Program for Undergraduate Research (SPUR), Wharton School, University of Pennsylvania, viewed 09 July 2017, from http://repository. upenn.edu/cgi/viewcontent.cgi?article $=1000 \&$ context=spur

Darwish, T.K. \& Singh, S., 2013, 'Does strategic human resource involvement and development enhance organisational performance?', International Journal of Manpower 34(6), 674-692. https://doi.org/10.1108/IJM-01-2012-0003

Deimel, M., Frentrup, M. \& Theuvsen, L., 2011, 'Transparency and constraints in food supply chains: Empirical results from German pig and dairy production', Journal on Chain and Network Science 8, 21-32. https://doi.org/10.3920/JCNS2008.x086

De Jong, G., Phan, T.B. \& Van Ees, H., 2011, 'Does the meta-environment determine firm performance? Theory and evidence from European multinational enterprises', International Business Review 20(4), 454-465. https://doi.org/ 10.1016/j.ibusrev.2010.08.003

Denisi, A. \& Smith, C., 2014, 'Performance appraisal, performance management, and firm-level performance: A review, a proposed model, and new directions for future research', Academy of Management Annals 8(1), 127-179. https://doi.org $/ 10.1080 / 19416520.2014 .873178$

Department of Agriculture, Forestry and Fisheries, 2014, Quarterly Economic Review of the food and beverages industry in South Africa, July to September 2014 viewed 11 April 2017, from www.nda.agric.za/.../AgroProcessingSupport/... Quarterly $\% 20$ review $\% 2$ fofood $\% 20$ be

Department of Higher Education, 2016, List of occupations in high demand 2015, Government Gazette No. 39604, 19 January 2016, viewed 02 July 2017, from http://www.dhet.gov.za/Gazette/Government $\% 20$ Gazette $\% 20$ No\% 20 $39604, \% 2019 \% 20$ January $\% 202016$. $\% 2$ List $\% 20$ of $\% 20$ Occupations $\% 20$ in $\% 20$ High\%20Demand\%202015.pdf

Dharni, K. \& Rodrigue, R.K., 2015, 'Supply chain management in food processing sector: Experience from India', International Journal of Logistics Systems and Management 21(1), 115-132. https://doi.org/10.1504/IJLSM.2015.069080

Dutu, C. \& Halmajan, H., 2011, 'The effect of organizational readiness on CRM and business performance', International Journal of Computers 5(1), 106-114.

Elmualim, A., Vallie, R. \& Kwawu, W., 2012, 'Discerning policy and drivers for sustainable facilities management practice', International Journal of Sustainable Built Environment 1, 16-25. https://doi.org/10.1016/j.ijsbe.2012.03.001

Eriksson, M., Strid, I. \& Hansson, P.A., 2012, 'Food losses in six Swedish retail stores: Wastage of fruit and vegetables in relation to quantities delivered', Resources, Conservation and Recycling 68, 14-20. https://doi.org/10.1016/j. resconrec.2012.08.001

Esper, T., Fugate, B. \& Davis-Sramek, B., 2007, 'Logistics learning capability: Sustaining the competitive advantage through logistics leverage', Journal of Business Logistics 28(2), 57-81. https://doi.org/10.1002/j.2158-1592.2007.tb00058.x

Fedderke, J. \& Szalontai, G., 2012, 'Industry concentration in South African manufacturing industry: Trends and consequences', Economic Modelling 26(1) 241-250. https://doi.org/10.1016/j.econmod.2008.07.005

Forsman, H. \& Temel, S., 2011, 'Innovation and business performance in smal enterprises: An enterprise-level analysis', International Journal of Innovation Management 15(3), 641-665. https://doi.org/10.1142/S1363919611003258

Gadde, L.E., Håkansson, H. \& Persson, G., 2010, Supply network strategies, 2nd edn. Wiley, Chippenham.

Genest, C. \& Nešlehová, J., 2009, 'Analytical proofs of classical inequalities between Spearman's rho and Kendall's tau', Journal of Statistical Planning and Inference 139, 3795-3798.

Gold, S., Seuring, S. \& Beske, P., 2011, 'Sustainable supply chain management and inter organizational resources: A literature review', Corporate Social Responsibility and Environmental Management 17, 230-245.

Greenberg, S., 2013. The disjuncture of land and agricultural reform in South Africa: Implications for the agri-food system, Institute for Poverty, Land and Agrarian Studies, Working Paper 26, viewed 24 June 2016, from http://www. plaas.org.za/ sites/default/files/publications-pdf/WP26Greenberg.pdf

Groenmeyer, S., 2013, 'The right to food sovereignty for small scale farmers: Case study of farming cooperatives in Limpopo province, South Africa', Internationa Journal of Social Science Studies 1(2), 168-180. https://doi.org/10.11114/ijsss. v1i2.180

Grover, A.K., Chopra, S. \& Mosher, G.A., 2016, 'Food safety modernization act: A quality management approach to identify and prioritize factors affecting adoption of preventive controls among small food facilities', Food Control 66, 241-249. https://doi.org/10.1016/j.foodcont.2016.02.001

Groznika, A. \& Trkman, P., 2012, 'Current issues and challenges of supply chain management', Economic Research-Ekonomska Istraživanja 25(4), 1101-1112. https://doi.org/10.1080/1331677X.2012.11517551

Gulati, M., Jacobs, I., Jooste, A., Naidoo, D. \& Fakir, S., 2013, 'The water-energy-food security nexus: Challenges and opportunities for food security in South Africa', Aquatic Procedia 1, 150-164. https://doi.org/10.1016/j.aqpro.2013.07.013

Gupta, S. \& Palsule-Desai, O.D., 2011, 'Sustainable supply chain management: Review and research opportunities, Indian Institute of Management Bangalore Management Review 23, 234-245.

Guthrie, J.P. \& Messersmith, J., 2010, 'High performance work systems in emergent organizations: Implications for firm performance', Human Resource Management 49(2), 241-264. https://doi.org/10.1002/hrm.20342

Guttman, L., 1954, 'Some necessary conditions for common-factor analysis', Psychometrika 19, 149-161. https://doi.org/10.1007/BF02289162 
Halldorsson, A., Kotzab, H., Mikkola, J.H. \& Skjøtt-Larsen, T., 2007, 'Complementary theories to supply chain management', Supply Chain Management 12, 284-296. https://doi.org/10.1108/13598540710759808

Hoffman, P., Schiele, H. \& Krabbendam, K., 2013, 'Uncertainty, supply risk management and their impact on performance', Journal of Purchasing and Supply Management 19, 199-211. https://doi.org/10.1016/j.pursup.2013.06.002

Industrial Development Corporation, 2016, Economic trends: Key trends in the South African economy, viewed 10 April 2017, from https://www.idc.co.za/home/mediaroom/articles/682-key-trends-in-the-south-african-economy,-31-march-2014.htm

Industrial Development Corporation, 2017, Economic trends: Key trends in the South African economy, viewed 09 July 2017, from https://www.idc.co.za/images/2017/ IDC_RI_publication_Key-trends-in-SA-economy_31-March-2017.pdf

International Trade Administration, 2016, South Africa - Agricultural sector, viewed 02 July 2017, from https://www.export.gov/article?id=South-Africa-agriculturalequipment

Jackson, J.H. \& Mathis, R.L., 2012, Human resource management: Essential perspectives, 6th edn., South-Western, Mason, $\mathrm{OH}$

Jackson, S.E., Schuler, R.S. \& Jiang, K., 2014, 'An aspirational framework for strategic human resource management', The Academy of Management Annals 8(1), 1-56. https://doi.org/10.1080/19416520.2014.872335

Janvier-James, A.M., 2012, 'A new introduction to supply chains and supply chain management: Definitions and theories perspective', International Business Research 5(1), 194-207.

Junghans, A., 2011, 'State of the art in sustainable facility management', pape presented at the 6th Nordic Conference on Construction Economics an Organisation, 13-15th April Copenhagen, Denmark.

Kaiser, H.F., 1974, 'An index of factorial simplicity', Psychometrika 39, 31-36.

Kamel, A.F., Vinod, K. \& Uma, K., 2010, 'Supply management practices and performance in the Canadian hospitality industry', International Journal of Hospitality Management 29(4), 685-693. https://doi.org/10.1016/j.ijhm.2010.02.001

Karia, N. \& Wong, C.Y., 2013, 'The impact of logistics resources on the performance of Malaysian logistics service providers', Production Planning \& Control: The
Management of Operations 24(7), 589-606. https://doi.org/10.1080/09537287. 2012.659871

Katz, M.H., 2006, Multivariable analysis - A practical guide for clinicians, 2nd edn. Cambridge University Press, Cambridge.

Kepe, T. \& Tessaro, D., 2014, 'Trading off: Rural food security and land rights in South Africa', Land Use Policy 36, 267-274. https://doi.org/10.1016/j.landusepol. 2013.08.013

Kherbach, Q. \& Mocan, A., 2016, 'The importance of logistics and supply chain management in the enhancement of Romanian SMEs', Procedia - Social and Behavioral Sciences 221, 405-413. https://doi.org/10.1016/j.sbspro.2016.05.130

Kimelberg, S.M. \& Williams, E., 2013, 'Evaluating the importance of business location factors: The influence of facility type', Growth and Change: A Journal of Urban Regional Policy 44(1), 92-117.

Klein, D. \& DeBruine, M., 2011, 'A thinking process for establishing management policies', Review of Business 16(3), 31-37.

Kock, N. \& Lynn, G.S., 2012, 'Lateral collinearity and misleading results in variancebased SEM: An illustration and recommendations', Journal of the Association for Information Systems 13(7), 546-580.

Koh, S.C., Demirbag, M., Bayraktar, E., Tatoglu, E. \& Zaim, S., 2011, 'The impact of supply chain management practices on performance of SMEs', Industria Management and Data Systems 107, 103-124.

Kosgei, R.C. \& Gitau, R., 2016, 'Effect of supplier relationship management on organizational performance: A case study of Kenya Airways Limited', International Academic Journal of Procurement and Supply Chain Management 2(2), 134-148.

Kubi, B.A. \& Doku, A.K., 2010, 'Towards a successful customer relationship management: A conceptual framework', African Journal of Marketing Management 2(3), 37-43.

Kumar, D. \& Bala, M., 2013, 'Supply chain risks in today's economy', Journal of Management 1(2), 53-62.

Lambert, M., 2014, Supply chain management: Processes, partnerships, performance, 4th edn., Supply Chain Management Institute, San Diego, CA.

Lavrakas, P.J., 2007, 'Cross-sectional survey design', in Encyclopedia of survey research methods, viewed 20 February 2017, from http://methods.sagepub.com/ reference/encyclopedia-of-survey-research-methods/n120.xml

Lee, C., Lee, K. \& Pennings, J.M., 2001, 'Internal capabilities, external networks and performance: A study on technology-based ventures', Strategic Management Journal 22(6), 615-640. https://doi.org/10.1002/smj.181

Lee, H.L., 2010, 'Taming the bullwhip', Journal of Supply Chain Management 46(1), 1-7. https://doi.org/10.1111/j.1745-493X.2009.03180.x

Lewis, C., 2017, 'Top 5 African economies', African Business Review, viewed 09 July 2017, from http://www.africanbusinessreview.co.za/finance/2673/Top-5-Africaneconomies

Lewis, D., Hodge, N., Gamage, D. \& Whittaker, M., 2012, 'Understanding the role of technology in health information systems', Pacific Health Dialogue 18(1), 144-166.

$\mathrm{Li}, \mathrm{X}$., 2014, 'Operations management of logistics and supply chain: Issues and directions', Discrete Dynamics in Nature and Society 20(4), 1-7. https://doi. org/10.1155/2014/701938

Liu, C., Li, Q. \& Zhao, X., 2012, 'Challenges and opportunities in collaborative business process management: Overview of recent advances and introduction to the special issue', Information Systems Frontiers 11(3), 201-209. https://doi.org/ 10.1007/s10796-008-9089-0
Lockström, M., Schadel, H., Moser, R. \& Malhotra, M., 2010, 'Antecedents to supplier integration in the automotive industry: A multiple-case study of foreign
subsidiaries in China', Journal of Operations Management 28, 240-257. https:// doi.org/10.1016/j.jom.2009.11.004

Lorentz, H., 2009, Contextual supply chain constraints in emerging markets: Exploring implications for foreign firms, Sarja/series A-6, Turku School of Economics, viewed 12 April 2017, from https://www.doria.fi/bitstream/handle/10024/113660/ Ae6 2009.pdf? sequence $=1$

Lu, C.S. \& Yang, C.C., 2010, 'Logistics service capabilities and firm performance of international distribution center operators', Service Industries Journals 30(2), 281-298. https://doi.org/10.1080/02642060802123392

Mafini, C., Pooe, D.R.I. \& Loury-Okoumba, V.W., 2016, 'Interrogating antecedents to SME supplier performance in a developing country', Southern African Business Review 20, 259-285.

Maletic, M., Maletic, D., Dahlgaard, J.J., Dahlgaard-Park, S.M. \& Gomiscek, B., 2015 'Effect of sustainability-oriented innovation practices on the overall company performance: An empirical examination', International Journal of Business Performance 3, 1-20.

Mcafee, R.B., Glassman, M. \& Honeycutt, J.R., 2002, 'The effects of culture and human resource management policies on supply chain management strategy', Journal of Business Logistics 23(1), 1-18. https://doi.org/10.1002/j.2158-1592.2002.tb00013.x

McLachlan, M. \& Landman, A.P., 2013, 'Nutrition: Sensitive agriculture: A South African perspective', Food Security 5(6), 857-871.

Mikes, A. \& Kaplan, R.S., 2013, Managing risks: Towards a contingency theory of enterprise risk management, Working Paper 13-063, Harvard Business School, Boston, MA.

Mishra, D.P., 2012, 'FMCG distribution channels in India: Challenges and opportunities for manufacturers and retailers', Journal of Global Business Issues 2(2), 125-182.

Moore, M., 2012, 'Interactive media usage among millennial consumers', Journal of ConsumerMarketing29(6),436-444.https://doi.org/10.1108/07363761211259241

Msimangira, K.A.B. \& Venkatraman, S., 2014, 'Supply chain management integration: Critical problems and solutions', Operations and Supply Chain Management 7(1), 23-31.

Munzhedzi, H., 2011, 'Performance management system and improved productivity: A case of the department of local government and housing in the Limpopo Province', unpublished master's dissertation, UNISA, Pretoria, South Africa.

Muduli, A., 2015, 'High performance work system, HRD climate and organisational performance: An empirical study', European Journal of Training and Development 39(3), 239-257. https://doi.org/10.1108/EJTD-02-2014-0022

Nikolić, D., Muresan, R.C., Feng, W. \& Singer, W., 2012, 'Scaled correlation analysis: A better way to compute a cross-correlogram', European Journal of Neuroscience $35,742-762$

O'Brien, R.M., 2007, 'A caution regarding rules of thumb for variance inflation factors', Quality and Quantity 41, 673-690.

Otchere, A.F., Annan, J. \& Anin, E.K., 2013, 'Achieving competitive advantage through supply chain integration in the cocoa industry: A case study of Olam Ghana limited and produce buying company limited', International Journal of Business and Socia Research 3(2), 131-145.

Paiva, E.L., 2010, 'Manufacturing and marketing integration from a cumulative capabilities perspective', International Journal of Production Economics 126(2), 379-386. https://doi.org/10.1016/j.ijpe.2010.04.031

Pamela, D. \& Pietro, R., 2011, 'Supply chain integration and efficiency performance: A study on the interactions between customer and supplier integration', Supply Chain Management: An International Journal 16, 220-230.

Paul, A.K. \& Anantharaman, R.N., 2003, 'Impact of people management practices on organizational performance: Analysis of a causal model', International Journal of Human Resource Management 14(7), 1246-1266. https://doi.org/10.1080/ 0958519032000145648

Perry, C., 2012, 'The impact of supply chain business processes on competitive advantage and organizational performance', unpublished master's dissertation, Department of Operational Sciences, Air University, Islamabad, Pakistan.

Pillay, P. \& Mafini, C., 2017, 'Supply chain bottlenecks in the South African construction industry: Qualitative insights', Journal of Transport and Supply Chain Managemen 11(0), a307. https://doi.org/10.4102/jtscm.v11i0.307

Punch, F.K., 2003, Survey research: The basics, Sage, London.

Rauta, R.D., Narkhede, B. \& Gardas, B., 2017, 'To identify the critical success factors of sustainable supply chain management practices in the context of oil and gas industries: ISM approach', Renewable and Sustainable Energy Reviews 68, 33-47. https://doi.org/10.1016/j.rser.2016.09.067

Redlein, A., Loeschl, J. \& Fuke, F., 2015, 'Corporate social responsibility and facility management in Europe', in International Facilities Management Association Academic and Research Track Conference Proceedings, pp. 1-10, viewed 09 July 2017, from https://foundation.ifma.org/docs/default-source/default-document-library/2015-aand-r-papers-proceedings547434b06c9e62f887dcff0000d243a1.pdf?sfvrsn=0

Ren, S.K., 2010, 'Game analysis on the technological choices and government system innovation', Statistics and Decision 13(2), 167-170.

Resse, A.K., 2011, 'Extending quality into global supply chains', Supply \& Demand Chain Executive 10(3), 18-26.

Revilla, E. \& Sáenz, M.J., 2014, 'Supply chain disruption management: Global convergence versus national specificity', Journal of Business Research 67, 11231135. https://doi.org/10.1016/j.jbusres.2013.05.021

Richardson, L.J. \& Snaddon, D.R., 2011, 'An exploratory study of long supply chain competition: Selected cases in the South African aerospace sector', South African Journal of Industrial Engineering 22(1), 155-165. https://doi.org/10.7166/22-1-39 
Root, D., Fellows, R. \& Hancock, M., 2013, 'Quantitative versus qualitative or positivism and interactionism - A reflection of ideology in the current methodological debate', Journal of Construction Procurement 3(4), 34-44.

Salkind, N.J., 2012, Exploring research, 8th edn., Pearson Education, Upper Saddle River, NJ.

Scupola, A., 2012, 'Managerial perception of service innovation in facility management organizations', Journal of Facility Management 10(3), 198-211. https://doi. org/10.1108/1472596121124600

Shafritz, J., Russell, E.W. \& Borick, C., 2012, 'Introducing public administration', International Journal of Business Administration 8, 1-145.

Shwu, I.W. \& Chien, L.L., 2012, 'The relationship between CRM, RM, and business performance: A study of the hotel industry in Taiwan', International Journal of Hospitality Management 31(1), 276-285. https://doi.org/10.1016/j.ijhm.2011.06.012

South African Government, 2017, South Africa's provinces, viewed 09 July 2017, from http://www.gov.za/about-sa/south-africas-provinces\#gp

South African National Bottled Water Association, 2016, SANBWA comments on illegal bottled water operations, viewed 11 April 2017, from http://www.foodreview. co.za/news/1940-sanbwa-tackles-water-fraud

South African Poultry Association (SAPA), 2013, Poultry commodity balance sheet South African Poultry Association, Pretoria, South Africa.

South African Poultry Association (SAPA), 2017, South African meat imports, viewed 02 July 2017, from https://www.sapoultry.co.za/pdf-statistics/summary-importsreport.pdf

Statistics South Africa, 2016, Food and beverages (preliminary), Statistical release P6420, Statistics South Africa, Pretoria, viewed 11 April 2017, from http://www. statssa.gov.za/publications/P6420/P6420February2014.pdf

Statistics South Africa, 2017, Manufacturing: Production and sales (preliminary) Statistical release P3041.2, Statistics South Africa, Pretoria, viewed 13 April 2017 , from http://www.statssa.gov.za/?page_id=1854\&PPN=P3041.2

Steyn, M., Monismith, C.L., Nokes, W.A., Harvey, J.T., Holland, T.J. \& Burmas, N., 2012 'Challenges confronting road freight transport and the use of vehicle-pavement interaction analysis in addressing these challenges', Journal of the South African Institution of Civil Engineering 54(11), 4-21.

Steyn, N.P. \& Labadarios, D., 2011, 'Street foods and fast foods: How much do South Africans of different ethnic groups consume?', Ethnicity and Disease 21, 462-466.

Stuart, F.J., Verville, J. \& Taskin, N., 2012, 'Trust in buyer-supply relationships: Supplie competency, interpersonal relationships and performance outcomes', Journal of Enterprise Information Management 25(4), 392-412. https://doi.org/10.1108/ 17410391211245856

Sullivan, G.M., 2011, 'A primer on the validity of assessment instruments', Journal of Graduate Medical Education 3, 119-120. https://doi.org/10.4300/JGME-D-1100075.1

Sweeney, J.C., Soutar, G.N. \& McColl-Kennedy, J.R., 2011, 'The marketing practices performance relationship in professional service firms', Journal of Service Management 22(3), 292-316. https://doi.org/10.1108/09564231111136845

Sukati, I., Abdul Hamid, A.B. \& Baharun, R., 2013, 'Testing the effect of the supply chain management implementation on business performance: An empirical study', International Business Research 6(1), 76-89.

Tabachnick, B.G. \& Fidell, L.S., 2007, Using multivariate statistics, 5th edn., Allyn \& Bacon, Boston, MA.

Tangpong, C., Michalisin, M.D., Traub, R.D. \& Melcher, A.J., 2015, 'A review of buyersupplier relationship typologies: Progress, problems, and future directions', Journal of Business \& Industrial Marketing 30(2), 153-170. https://doi.org/ 10.1108/JBIM-10-2012-0193

Tavakol, M. \& Dennick, R., 2011, 'Making sense of Cronbach's alpha', International Journal of Medical Education 2, 53-55.

Tavitiyaman, P., Qu, H. \& Zhang, H., 2011, 'The impact of industry force factors on resource competitive strategies and hotel performance', International Journal of Hospitality Management 30, 648-657. https://doi.org/10.1016/j.ijhm.2010.11.010

Thakur, M. \& Hurburgh, C.R., 2009, 'Framework for implementing traceability system in the bulk grain supply chain', Journal of Food Engineering 95(4), 617-626. https://doi.org/10.1016/j.jfoodeng.2009.06.028

Tseng, Y.Y., Taylor, M.A.P. \& Yue, W.L., 2005, 'The role of transportation in logistics chain', Proceedings of the Eastern Asia Society for Transportation Studies 5 , 1657-1672.
Tsoulfas, G. \& Pappis, C., 2006, 'Environmental principles applicable to supply chains design and operation', Journal of Cleaner Production 14(18) 1593-1602. https:// doi.org/10.1016/j.jclepro.2005.05.021

Tu, P.A., 2012, 'The impact of entrepreneurial characteristics on bribery incidence in transition economies', Asia Academy of Management Journal 17(2), 155-175.

Tuominen, T., Kitaygorodskaya, N. \& Helo, P., 2011, 'Benchmarking Russian and finished food supply chains', Benchmarking: An International Journal 16(3), 415-431. https://doi.org/10.1108/14635770910961416

Tucker, M. \& Pitt, M., 2009, 'Customer performance measurement in facility management', International Journal of Productivity and Performance Management 56(5), 407-442. https://doi.org/10.1108/17410400910965698

Van der Vorst, J., Beulens, A. \& Van Beek, P., 2013, 'Innovations in logistics and information technologies in food supply chain networks', Innovations in Agri-food Systems, Product Quality and Consumer Acceptance 23, 245-292.

Van der Merwe, C., 2011, Key challenges for ensuring food security in South Africa's inner cities, Africa Institute of South Africa No. 36, viewed 07 April 2017, from http://dspace.africaportal.org/jspui/bitstream/123456789/33805/1/No-36.-KeyChallenges-for-Ensuring-Food-Security-in-South-Africas-Inner-Cities.pdf?1

Van de Voorde, K., Paauwe, J. \& Van Veldhoven, M., 2010, 'Predicting business unit performance using employee surveys: Monitoring HRM-related changes', Human performance using employee surveys: Monitoring HRM-related changes', Human
Resource Management Journal 20(1), 44-63. https://doi.org/10.1111/j.1748Resource Managem
8583.2009.00114.x

Van Rooyen, J., Esterhuizen, D. \& Stroebel, L., 2011, 'Analyzing the competitive performance of the South African Wine Industry', International Food and Agribusiness Management Review 14(4), 179-200.

Verdouw, C.N., Beulens, A., Trienekens, J. \& Wolfert, J., 2010, 'Process modelling in demand-driven supply chains: A reference model for the fruit industry', Computers and Electronics in Agriculture 73, 174-187.

Vij, S. \& Bedi, H.S., 2016, 'Are subjective business performance measures justified?', International Journal of Productivity and Performance Management 65(5), 603621. https://doi.org/10.1108/IJPPM-12-2014-0196

Wang, I.C., Huang, C.Y., Chen, Y. \& Lin, Y., 2010, 'The influence of customer relationship management process on management performance', International Journal of Organization Innovation 2(3), 40-50.

Wang, Y. \& Feng, H., 2012, 'Customer relationship management capabilities: Measurement, antecedents and consequences', Management Decision 50(1), 115-129. https://doi.org/10.1108/00251741211194903

Warne, R.G. \& Larsen, R., 2014, 'Evaluating a proposed modification of the Guttman rule for determining the number of factors in an exploratory factor analysis', Psychological Test and Assessment Modeling 56, 104-123.

Widodo, K.H., Nagasawa, H., Morizawa, K. \& Ota, M., 2006, 'A periodical flowering harvesting model for delivering agricultural fresh products', European Journal of Operational Research 170, 24-43. https://doi.org/10.1016/j.ejor.2004.05.024

Woods, E.J., 2014, 'Supply-chain management: Understanding the concept and its implications in developing countries', Journal of Supply Chain Management 119, 18-25.

Yildiz, S., 2010, 'A study on measuring business performance in banking sector', Erciyes University Faculty of Economy and Administrative Sciences Journal 36, 179-193.

Yildiz, S. \& Karakaş, A., 2012, 'Defining methods and criteria for measuring business performance: A comparative research between the literature in Turkey and foreign', Procedia - Social and Behavioral Sciences 58, 1091-1102. https://doi. org/10.1016/j.sbspro.2012.09.1090

Zhang, Z., Wan, D. \& Jia, M., 2009, 'Do high-performance human resource practices help corporate entrepreneurship? The mediating role of organizational citizenship behavior', Journal of High Technology Management Research 19, 128-138. https://doi.org/10.1016/j.hitech.2008.10.005

Zhou, H. \& Benton, W.C., 2010, 'Supply chain practice and information sharing', Journal of Operations Management 25(6), 1348-1365. https://doi.org/10.1016/j jom.2007.01.009

Zhu, Q., Sarkis, J. \& Lai, K., 2012, 'Green supply chain management innovation diffusion and its relationship to organizational improvement: An ecological modernization perspective', Journal of Engineering and Technology Management 29, 168-185. https://doi.org/10.1016/j.jengtecman.2011.09.012

Zulkiffli, S.N.A., 2014, 'Business performance for SMEs: Subjective or objective measures?', Review of Integrative Business and Economics Research 3(1), 371-381. 


\section{APPENDIX 1}

\section{MEASUREMENT SCALES USED IN THE STUDY}

\section{SUPPLY CHAIN MANAGEMENT CHALLENGES}

Please indicate the extent to which you either agree or disagree with how your business organisation has achieved each of the following in the past year.

(Five-point scale: 1 = Strongly disagree; 2 = Disagree; 3 = Neutral; 4 = Agree; 5 : Strongly agree)

- Turnover of skilled personnel is low in your business

- There is a high utilisation of employee skills and abilities in your business

- Staff in your business are fully trained in supply chain concepts and management

- Your business faces labour relations challenges such as industrial action, lock-outs and high absenteeism

- Your business is fast in adopting new technologies

- Your business has managed to integrate technology with suppliers and customers

- Your business conducts regular technology forecasts to understand the trends in the environment

- Your business has recent technology that links it to internal and external stakeholders

- The facilities at your business are managed professionally through tracking resource consumption and conducting on-site audits

- The facilities at your business are adequate for packaging reduction, reuse and recycling of materials

- Your business has a written corporate social responsibility policy or statement of commitments that defines the labour, health and safety standards

- Your business has sufficient facility capacity which enables it to deal with customer order fluctuations

- The storage facilities at your business are adequate

- Suppliers to your business charge the right price for their products

- Suppliers to your business have ISO 9001 certification

- Suppliers to your business have the capacity to provide the right quantity of materials

- Information flow between your business and its suppliers is free and effective

- Suppliers to your business are able to deliver materials on time

- There are high levels of trust between your business and its customers

- Information flow between your business and its customers is very free and effective

- Your business is very effective at meeting customer needs

- Your business rapidly accommodates special or non-routine customer requests

- The level of your business' brand reputation among customers is very high

- Your business is experiencing uncertainties in meeting government supply chain management policies

- Your business faces challenges in meeting the prescribed health and safety regulations

- Your business has adopted effective environment practices

- Your business has a greater responsiveness in meeting the lead time and point of delivery

- Your business has modern and state-of-the-art transportation equipment and machinery

- Your business encounters problems with packaging material while in transit

- The distribution channels used by your business are very effective

\section{BUSINESS PERFORMANCE SCALE}

Please rate your business organisation's performance in each of the following areas as compared to the industry average.

(Five-point scale: 1 = Much worse than industry average; $2=$ Worse than industry average; $3=$ Neutral; $4=$ Better than industry average 5 : Much better than industry average)

- Return on investment

- Sales growth

- Profit growth

- Customer satisfaction

- Employee satisfaction 